\title{
Using informal knowledge to infer human-induced rarity of a conspicuous reef fish
}

\author{
Nicholas K. Dulvy* and Nicholas V. C. Polunin \\ School of Marine Science and Technology, Ridley Building, University of Newcastle, Newcastle-upon-Tyne, NE1 7RU, UK. \\ (Received 3 September 2003; accepted 1 March 2004)
}

\begin{abstract}
There have been few contemporary extinctions in the sea, which suggests marine species are either less vulnerable to extinction than terrestrial species, or marine extinctions may have gone unnoticed. We consider whether a large conspicuous reef fish, the giant humphead parrotfish (Bolbometopon muricatum), is likely to have declined across much of its geographical range. Informal knowledge was used to determine the status of the giant humphead parrotfish. We first surveyed fishers' knowledge of this parrotfish at 12 lightly exploited islands in the Lau group, Fiji and then compiled a global inventory of available information. In the Lau islands, Fiji, fishers reported this parrotfish as previously abundant, but it had not been caught at six islands since at least 1990 and was considered rare at another four islands. The parrotfish had been captured recently (since the 1990s) at three islands where fishers did not target parrotfishes regularly. A compilation of giant humphead parrotfish records provided by local scientists at 39 locations in 31 Indo-Pacific nations suggested this fish is locally common only inside areas where fishing is prohibited and that it is currently globally rare. Local densities of the giant humphead parrotfish were negatively correlated to a categorical scale of fishing pressure across six Indo-Pacific locations. The retrospective discovery of local disappearances and global rarity of a distinctive and formerly prominent reef fish is consistent with the hypothesis that the capacity to detect disappearances of exploitation-vulnerable species in the sea is lower than expected.
\end{abstract}

\section{INTRODUCTION}

For the last 1000 years humans have fished down coastal shelf and oceanic food webs (Jackson et al., 2001; Wing \& Wing, 2001; Myers \& Worm, 2003). Despite these major and widespread impacts, no marine fish are known to have become globally extinct (Carlton et al., 1999; Roberts \& Hawkins, 1999; Dulvy, Sadovy \& Reynolds, 2003). Also, few marine fishes $(n=160)$ have been categorised as threatened under World Conservation Union Red List criteria (Hilton-Taylor, 2000). There are two possible explanations: marine fishes are less extinction prone than terrestrial species (McKinney, 1998) or their extinctions go unnoticed (Carlton et al., 1999; Roberts \& Hawkins, 1999; Dulvy et al., 2003).

Marine species were previously considered to be resilient to extinction due to large geographical ranges, high fecundity and broadcast spawning (Hudson \& Mace, 1996; Mace \& Hudson, 1999; Powles et al., 2000). This orthodoxy has been challenged as a number of fecund and wide-ranging fish populations are threatened with extinction (Roberts \& Hawkins, 1999; Hawkins, Roberts \&

\footnotetext{
*All correspondence to: N. K. Dulvy. Current address: Centre for Environment, Fisheries and Aquaculture Science, Pakefield Road, Lowestoft, Suffolk, NR33 OHT, UK. Tel: +44 (0) 1503 524272; Fax: +44 (0) 1502 513865; E-mail: n.k.dulvy@cefas.co.uk
}

Clark, 2000; Sadovy, 2001; Reynolds, Dulvy \& Roberts, 2002; Dulvy et al., 2003; Sadovy \& Cheung, 2003). Some species have declined to the point of near extinction at a local scale, e.g. common skate (Dipturus batis) in the Irish Sea (Brander, 1981). Not only are fishes vulnerable to declines and disappearances, but they do not recover as rapidly as previously thought (Hutchings, 2000, 2001a,b). Recent comparative studies suggest there is little difference in extinction risk or resilience between marine fishes and either freshwater fishes or birds, mammals and butterflies (Hutchings, 2001a; Dulvy et al., 2003; Reynolds, 2003). If extinction vulnerability of marine species is higher than previously thought, it seems timely to consider why marine extinctions might go undetected.

The relative paucity of marine extinctions could be interpreted as evidence that extinctions have not occurred. However, this assumes that all marine extinctions were documented as they happened. If this were correct there should be no lag between the extinction date and the detection date. Evidence for any time lag between the extinction date and the date of detection indicates underestimation of marine extinctions. Assuming date of last sighting approximates to the date of extinction and the reporting date approximates to the detection date, then a reporting lag can be estimated. A review of 133 marine extinctions recorded at local, regional and global scales found a reporting lag of approximately 50 years 
between the date of last sighting and the reported date of extinction (Dulvy et al., 2003). Most disappearances ( $80 \%$ of the total) were detected retrospectively using indirect historical comparative methods (Dulvy et al., 2003). Direct detection methods may be used to monitor declines and minimise reporting lag, however census power decreases as the remaining number of individuals decline. This is illustrated by the uncertainty surrounding the degree of collapse of Baltic and Canadian cod populations (Gadus morhua) and the barndoor skate (Dipturus laevis) (Hutchings, 1996; Myers, Hutchings \& Barrowman, 1997; Casey \& Myers, 1998; Jonzén et al., 2001; Dulvy et al., 2003). The evidence for reporting lags, indirect detection and low power of direct census methods are consistent with the hypothesis that marine extinctions may have gone undetected.

Coral reef organisms face a number of threats, such as coral bleaching and the direct and indirect effects of fisheries exploitation (Hughes et al., 2003; Dulvy, Freckleton \& Polunin, 2004; Hawkins \& Roberts, 2004). Coral reef fishes are relatively simple to census using SCUBA, however the level of training required, diving logistics and safety limit the number of replicates, while the timing of sampling, the size of samples and their accuracy limit the power to detect speciesspecific trends (Mumby et al., 1995; Thompson \& Mapstone, 1997, 2002). This may be particularly acute for large rare species, some of which may be highly aggregated and found at extremely low densities, e.g. $<1$ individual $/ 10000 \mathrm{~m}^{2}$ (our unpublished data). The point census and strip transect techniques commonly used to survey reef fish assemblages are typically based on small replicate areas $\left(\sim 100-250 \mathrm{~m}^{2}\right)$, and only a relatively small area $\sim 1000-2000 \mathrm{~m}^{2}$ can be covered on each dive (St. John, Russ \& Gladstone, 1990; Jennings \& Polunin, 1997; Samoilys \& Carlos, 2000; Gust, Choat \& McCormick, 2001; Dulvy et al., 2002; Thompson \& Mapstone, 2002). Consequently power to detect changes in the abundance of single reef fish species may be low without complex designs and high levels of replication, especially against the relatively high background of daily, monthly and annual variation in densities (e.g. Galzin, 1987; Thompson \& Mapstone, 2002). Consequently suitable census data, at the appropriate temporal and spatial scales, are typically unavailable for determining whether a reef fish has actually gone extinct, e.g. the Galapagos Damselfish (Azurina eupalama) and the green wrasse (Anampses viridis: Hawkins et al., 2000).

Informal traditional knowledge may be used to detect declines or marine extinctions (Johannes, 1998). Local fishers' traditional knowledge has been used to detect and confirm the near extinction of the giant yellow croaker (Bahaba taipingensis) in China (Sadovy \& Cheung, 2003). Large-scale comparisons of local densities have the potential for improving detection because the wider range of species abundances should provide greater statistical power due to the larger effect size (Cohen, 1988).

Here we use both methods to make inferences on the conservation status of the potentially threatened giant humphead parrotfish (Bolbometopon muricatum)
(Donaldson \& Dulvy, 2004). The giant humphead parrotfish is the largest species of parrotfish, reaching $130 \mathrm{~cm}$ in length and $46 \mathrm{~kg}$ maximum weight and is long-lived reaching $>28$ years (Randall \& Bruce, 1983; Couture \& Chauvet, 1994; Kitalong \& Dalzell, 1994). It is one of the largest bony fishes (teleosts) found on coral reefs (Lieske \& Myers, 1994; Myers, 1999). It is unusual among the predominantly herbivorous parrotfishes in that it feeds on live corals, a large individual can consume $2-5$ tonnes of coral per year. Consequently this species may have a 'keystone' role in the regulation of reef growth (Bellwood, Hoey \& Choat, 2003). We conducted a questionnaire survey of traditional knowledge to determine the status of the giant humphead parrotfish at 13 islands in the Lau group, Fiji. This survey prompted us to collate all available information on the status of this species throughout its geographical range in the Indo-Pacific Ocean.

\section{METHODS}

\section{Questionnaire survey of giant humphead parrotfish catches}

Group questionnaire surveys at 14 villages on 12 islands were conducted by an interviewer using the regional dialect. Respondents were drawn from either the paramount village or the primary fishing village of each island and interviewed as a group. An average of ten respondents were questioned at each island including chiefs, village government representatives and fishers having a good knowledge of local fishing activity and practices. Group interviews provided an overview and consensus of fishing practices and catches because the human populations were small and Fijian society is strictly hierarchical. Two specific questions were asked. Respondents were asked to state the last time a giant humphead parrotfish had been captured on their island. The frequency of capture of all parrotfishes (Scaridae) was determined by asking villagers to choose from three categories: 'regularly' on every fishing trip, 'occasionally' on every second or third fishing trip and 'rarely' once or twice a year.

\section{Status of giant humphead parrotfish in Indo-Pacific Oceans and Red Sea}

All available information was collated from national statistics, taxonomies, checklists and information provided by local scientists (see Acknowledgements, below). Where possible we extracted local-scale density estimates from the available information and correlated these to fishing intensity to test for a possible link between exploitation and parrotfish densities at the large scale. A subjective categorical scale of fishing intensity was used based on published catch rates, fin-fish yields, the authors' experience of the sites and discussion with regional scientists. The four point categorical scale used was: (0) no known fishing, (1) subsistence fishing for personal consumption, (2) light artisanal fishing with possible sale, (3) heavy artisanal fishing, including the use of habitat destructive methods (such as use of poisons or explosives) 
Table 1. Date of last capture of the giant humphead parrotfish and the frequency with which all parrotfish were targeted, based on a questionnaire survey of traditional knowledge in the Lau Islands, Fiji

\begin{tabular}{|c|c|c|c|c|c|}
\hline Island $^{\dagger}$ & Village & $\begin{array}{l}\text { Number of } \\
\text { respondents }\end{array}$ & Date of last capture & $\begin{array}{l}\text { Frequency of } \\
\text { parrotfish targeting }\end{array}$ & $\begin{array}{l}\text { Other comments on abundance and } \\
\text { fisheries }\end{array}$ \\
\hline Moala & Naroi $(p)$ & 7 & Question not asked & Regularly & $\begin{array}{l}\text { Occasionally captured but only caught } \\
\text { at night }\end{array}$ \\
\hline Matuku & Yaroi $(\mathrm{p})$ & $\sim 20$ & Question not asked & Regularly & Occasionally captured \\
\hline Totoya & Udu & 4 & $\begin{array}{l}\text { Cannot remember last } \\
\text { capture }\end{array}$ & Regularly & Perceived to be no longer present \\
\hline Kabara & Naikeleyaga (p) & $\sim 30$ & $1970 \mathrm{~s}$ & Regularly & $\begin{array}{l}\text { Reported as no longer available at this } \\
\text { island, only caught at other } \\
\text { uninhabited associated fishing } \\
\text { grounds (Vuaqava) }\end{array}$ \\
\hline$"$ & Lomati & 5 & $1980 \mathrm{~s}$ & Regularly & Not seen in recent years \\
\hline " & Udu & 4 & Not present & Occasionally & $\begin{array}{l}\text { Parrotfishes only caught at another } \\
\text { uninhabited associated fishing ground } \\
\text { (Marabo) controlled solely by this } \\
\text { village }\end{array}$ \\
\hline Fulaga & Muanicake (p) & 3 & $\begin{array}{l}\text { Last seen in late } \\
\text { 1960s }\end{array}$ & Regularly & $\begin{array}{l}\text { Species was perceived to have } \\
\text { disappeared, which was one reason } \\
\text { for the imposition of a night-time } \\
\text { spear fishing ban }\end{array}$ \\
\hline Namuka & Namuka (p) & 3 & Not known & Regularly & Rarely caught \\
\hline Komo & Komo (p) & 14 & Christmas 1998 & Occasionally & $\begin{array}{l}\text { It was reported that it takes a few } \\
\text { individual parrotfish of this species } \\
(\sim 7) \text { to feed the whole village }\end{array}$ \\
\hline Oneata & Waiqori (p) & 15 & c. $1970 \mathrm{~s}$ & Regularly & $\begin{array}{l}\text { Not caught within living memory and } \\
\text { some respondents were in their } \\
50 \text { s- } 60 \text { s. The species is known on the } \\
\text { basis of reports from fishers from } \\
\text { other islands, but no-one had ever } \\
\text { seen it themselves }\end{array}$ \\
\hline Lakeba & Tobuo (p) & 4 & March 1999 & Occasionally & $\begin{array}{l}\text { Previously captured using inshore fish } \\
\text { drive with leaf scares, now it is } \\
\text { believed to be scarce due to spear } \\
\text { fishing }\end{array}$ \\
\hline Vanuavatu & Taira (p) & 10 & c. $1980 \mathrm{~s}$ & Regularly & $\begin{array}{l}\text { Rarely seen, 'last caught about } 10 \text { years } \\
\text { ago' }\end{array}$ \\
\hline Tuvuca & Tuvuca (p) & 20 & 1996 & $\begin{array}{l}\text { Larger spp. captured } \\
\text { occasionally and smaller } \\
\text { spp. captured regularly }\end{array}$ & $\begin{array}{l}\text { This species is regarded as very rare } \\
\text { compared to } 5-10 \text { years ago, despite } \\
\text { the recent capture of one individual }\end{array}$ \\
\hline Cicia & Tarakua (p) & 2 & $1980 \mathrm{~s}$ & Regularly & $\begin{array}{l}\text { A fisherman noted without prompting } \\
\text { that this species was declining }\end{array}$ \\
\hline
\end{tabular}

$\dagger$ Each island comprised a single fishing ground or qoliqoli, apart from Kabara where some villages had sole access to other island qoliqoli (Marabo and Vuaqava).

(p), denotes a paramount village, the seat of the chief and associated hierarchy and government administration.

adjacent to densely populated areas. A fifth category of fishery, 'heavy artisanal fishing without use of destructive gears', could be considered, however none of the sites used in this study fell into this category. Measures of fishing activity, such as fish yield or catch per unit effort (CPUE) measures, could not be used to calculate a fishing pressure scale as both under- and overexploited reefs can exhibit similar yields or CPUE values (Dalzell \& Adams, 1997) and other quantitative data such as fishers or boats per unit area were not available.

\section{RESULTS}

Fishers and other villagers in the Lau Islands, Fiji, reported that historically this parrotfish was occasionally captured in daytime using 'leaf drives', where a net of twisted coconut leaves is used like a seine or purse net to encircle a shallow area of back reef within the lagoon. More often the parrotfish was captured using hand spears and spear guns at night. Fishers reported that this parrotfish aggregates in large numbers and shelters in reef caves and on sandy lagoon areas rendering it relatively easy to capture. The respondents reported that the giant humphead parrotfish had rarely been captured in the Lau Island group in the past decade. Local fishers reported the last date of capture was prior to the 1990s at six islands (Table 1). This species was captured recently (1990s) only at the three islands where parrotfishes were targeted only occasionally (Table 1). We did not have the opportunity to question the last capture date directly at three islands, however, from subsequent 
discussion we found that the inhabitants regarded the giant humphead parrotfish as rare (Table 1).

Information on the status of the giant humphead parrotfish was available for 39 locations in 31 IndoPacific nations (Table 2). The biogeographical range of giant humphead parrotfish included the Red Sea and western Indian Ocean to halfway across the Pacific Ocean, including Micronesia and Melanesia and western Polynesia. It seems that the giant humphead parrotfish was never present at Hawaii, the Cook Islands, Galapagos Islands, Lord Howe, Kermadec and Norfolk Islands. The parrotfish was abundant only in Australia's Great Barrier Reef Marine Park and Papua New Guinea and locally common in Western Samoa and at Sipidan Island, Malaysia. It was previously common in the Micronesian states of Yap and Palau in the 1980s but at all of the other locations it was uncommon or rare and is possibly locally extinct in Guam, the Marshall Islands and parts of Fiji.

In areas where the giant humphead parrotfish was common it has comprised a substantial proportion of fisheries landings. This parrotfish was the second most important commercial reef fish in Palau, 13 tonnes being sold between 1976-1990, which accounted for $10 \%$ of all landings (Kitalong \& Dalzell, 1994). It comprised 5\% of the landings from a small-scale artisanal fishery in 1980 in the lightly populated Tigak islands, Papua New Guinea (Wright \& Richards, 1985). In Fiji in 1990, the giant humphead parrotfish was the fifth most important species in terms of domestic commercial landings. A total of 230 tonnes was sold comprising 5\% of all species sold. It was the second most important reef fish landed, after coral trout (Plectropomus spp.), which comprised $6.5 \%$ of total landings (Anonymous, 1990). It is now extremely unusual to see this species sold in the main market in Suva, Fiji; one of the authors (N. K. D.) noted only one individual being sold between 1999-2000. A fisheries development programme was initiated at a small remote island, Kia Island, Fiji. (Anonymous, 1970). For the year up to July 1968 the experimental fishery yielded $22.3 \mathrm{t}$ of giant humphead parrotfish, which comprised $70 \%$ of the total catch (Anonymous, 1970). This indicates a catch rate of $\sim 300 \mathrm{~kg}$ of giant humphead parrotfish per $\mathrm{km}$ of fringing reef per year. Assuming the fringing reef was $100-300 \mathrm{~m}$ wide and $75 \mathrm{~km}$ in length then the standing biomass was $>1-3 \mathrm{~g}$ per $\mathrm{m}^{2}$, excluding lagoonal habitat.

Quantitative abundance data were available for only six locations (Table 3). Local densities of the giant humphead parrotfish were negatively correlated to the fishing intensity index $(t=-4.6, P<0.01)$. This parrotfish appeared to be locally extinct at the small study sites in Tanzania and the Philippines, which we have scored as having the highest levels of fisheries exploitation.

\section{DISCUSSION}

\section{Rarity in the giant humphead parrotfish}

We present evidence based on questionnaires of traditional knowledge to infer that the giant humphead parrotfish is locally extinct in some of the Lau Islands, Fiji. A key assumption of this approach is that the reported date of last capture reflects the absence of this species rather than a change in fisher behaviour or food preference. This was corroborated to some extent by fishers' perceptions that this species was no longer present or available. Also we observed only one shoal of 11 giant humphead parrotfish during $100 \mathrm{~h}$ of fish community census on the outer fringing coral reefs. This shoal was seen at Lakeba, an island where fishers do not target parrotfishes regularly and where the questionnaire survey revealed that this species had recently been captured (Table 1).

The larger scale compilation of informal knowledge also suggests that this species may be locally extinct at the Marshall Islands and possibly Guam (Table 2), however, this requires independent verification. It is still abundant in parts of the Great Barrier Reef, Australia and common or locally abundant in parts of Papua New Guinea and the Solomon Islands. This large conspicuous reef fish was formerly a prominent and abundant member of reef fish assemblages and catches, but is now encountered infrequently throughout large parts of its range.

\section{Is the rarity human-induced?}

There are a number of lines of evidence to suggest that the global rarity of this parrotfish may be linked to human activities, in particular fisheries exploitation. Throughout its geographical range this species is locally abundant almost exclusively at locations protected from exploitation, e.g. the Great Barrier Reef Marine Park, Australia (Bellwood et al., 2003), and in reserves in the Seychelles and Sipidan Island, Malaysia and at Wake Island, which was a US military air base until recently (Table 3). This parrotfish appears to also be abundant at the remote Rowley Shoals Marine Park in north-west Australia (Bellwood et al., 2003) and it is common or locally abundant in parts of Papua New Guinea and the Solomon Islands, which are lightly exploited because human densities are low relative to the area of reef habitat and agriculture provides sufficient food (Ruddle, 1996; Spalding, Ravilious \& Green, 2001; Aswani \& Hamilton, 2004).

There are a number of other reports linking declines to exploitation at other lightly fished locations, such as Palau and Fiji. In the 1980s and early 1990s this parrotfish was a major component of landings from reef fisheries in Palau and mainland Fiji. Palau's population of the giant humphead parrotfish is currently regarded as relatively small and fragile and is now protected by an export ban and a national minimum size restriction of 25 inches (Anonymous, 1998). There is also independent historical evidence to suggest that the species was locally very abundant at Kia Island, Fiji in the recent past; unfortunately we were unable to access any information on contemporary abundance.

The giant humphead parrotfish is consistently rare or very rare at locations with very high human population densities, such as the Philippines, Tanzania 
Table 2. Presence, abundance, status and exploitation of the giant humphead parrotfish in selected Indo-Pacific locations

\begin{tabular}{|c|c|c|c|c|c|}
\hline Region & Country & $\begin{array}{l}\text { Categorical } \\
\text { abundance }\end{array}$ & Abundance data & Exploitation patterns & Source \\
\hline Western Pacific & Australia & Abundant & $\begin{array}{l}\text { Third most abundant (in biomass) large herbivore } \\
\text { on outer GBR }\end{array}$ & $\begin{array}{r}\text { Protected marine } \\
\text { reserve system }\end{array}$ & H. J. Choat, pers. comm. \\
\hline Micronesia & Guam & V. rare/extinct & Disappeared, absent or extinct & Exploited & $\begin{array}{l}\text { Dalzell, Adams \& Polunin, 1996; } \\
\text { Myers, 1999; T. Donaldson, pers. comm. }\end{array}$ \\
\hline Micronesia & Marshall Is. & V. rare/extinct & None known & Not known & Myers, 1999 \\
\hline Micronesia & Palau & Present & $\begin{array}{l}\text { Rapidly declining, considered to be overexploited } \\
\text { by questionnaire survey }\end{array}$ & Exploited & Johannes, 1981; Myers, 1999 \\
\hline Micronesia & Palau & $\begin{array}{l}\text { Previously } \\
\text { common }\end{array}$ & $\begin{array}{l}\text { Moderately abundant, accounting for } 10 \% \text { of landings } \\
\text { between 1976-1990, } 13 \text { t sold per year in this } \\
\text { period. Landings peaked in } 1985 \text { and } \\
\text { subsequently declined }\end{array}$ & $\begin{array}{l}\text { Exploited exclusively } \\
\text { using spear guns }\end{array}$ & Nichols, 1991; Kitalong \& Dalzell, 1994 \\
\hline Micronesia & $\begin{array}{l}\text { Yap, Federated States } \\
\text { of Micronesia }\end{array}$ & Rare & $\begin{array}{l}0.6 \% \text { of all parrotfish by number in } 57 \text { snorkel/SCUBA } \\
\text { surveys }\end{array}$ & $\begin{array}{l}\text { Parrotfish are primary } \\
\text { target of fishers }\end{array}$ & Orcutt et al., 1989; Myers, 1999 \\
\hline Melanesia & New Caledonia & V. rare & $\begin{array}{l}127 \text { individuals out of a total of } 155,178 \text { parrotfish } \\
\text { recorded by UVC }\end{array}$ & Commercially sold & M. Kulbicki, pers. comm. \\
\hline Melanesia & PNG & $\begin{array}{l}\text { Common (prior } \\
\text { to } 1985 \text { ) }\end{array}$ & $\begin{array}{l}636 \text { captured in a catch survey, } 5.3 \% \text { of a } 22.5 \mathrm{t} \\
\text { sample }\end{array}$ & Exploited & Wright \& Richards, 1985 \\
\hline Melanesia & Solomon Is. & $\begin{array}{l}\text { Locally } \\
\quad \text { abundant }\end{array}$ & $\begin{array}{l}\text { Locally abundant at Marovo and Roviana lagoons. } \\
\text { Large component of night-time spear fishing } \\
\text { catches, populations have subsequently exhibited } \\
\text { declines }\end{array}$ & Subsistence fishery & $\begin{array}{l}\text { Samoilys et al., 1995; Aswani \& Hamilton, } \\
\quad 2004\end{array}$ \\
\hline Melanesia & N. PNG & Rare (1984-86) & $\begin{array}{l}\text { Seven caught in a trap survey of a total sample of } \\
632 \text { parrotfishes }\end{array}$ & Exploited & P. Dalzell, pers. comm. \\
\hline Melanesia & Fiji (Kadavu) & Rare & None seen in $\sim 168 \mathrm{~h}$ of $\mathrm{UVC}$ on outer reef & $\begin{array}{l}\text { Artisanal and possible } \\
\text { commercial }\end{array}$ & Jennings \& Polunin, 1997 \\
\hline Melanesia & Fiji (Lau) & $\begin{array}{l}\text { Rare/locally } \\
\text { extinct }\end{array}$ & $\begin{array}{l}\text { None caught at six islands for at least } 10 \text { years. Eleven } \\
\text { seen of a total sample of } 6000 \text { parrotfishes }\end{array}$ & Subsistence only & Anonymous, 1994; This study \\
\hline Melanesia & Fiji (Yadua taba) & Uncommon & Seen occasionally during UVC & Subsistence only & O. Taylor, pers comm. \\
\hline Melanesia & Fiji (Viti Levu) & Uncommon & $\begin{array}{l}\text { Major component of catch }(4.8 \%) \text { sold in the } \\
\text { domestic commercial market in } 1990 . \\
\text { Commercial market survey data indicates } \\
\text { declining trend from late } 1980 \text { s. Almost } \\
\text { absent in market in } 2000 .\end{array}$ & Artisanal and commercial & Anonymous, 1990; Ledua \& Vuki, 1998 \\
\hline Melanesia & Vanuatu & Uncommon & & & Williams, 1990 \\
\hline SW Pacific & $\begin{array}{l}\text { Lord Howe, } \\
\text { Kermadec, } \\
\text { Norfolk Is. }\end{array}$ & $\begin{array}{l}\text { Absent } \\
\text { Absent } \\
\text { Absent }\end{array}$ & $\begin{array}{l}13 \text { other parrotfish species present, but the } \\
\text { bumphead parrotfish may never have been } \\
\text { present }\end{array}$ & & Francis, 1993 \\
\hline Polynesia & $\begin{array}{c}\text { American } \\
\text { Samoa }\end{array}$ & Rare & $\begin{array}{l}\text { One individual recorded among } c .8000 \text { fish sampled } \\
\text { over } 18 \text { months }\end{array}$ & Exploited & M. Page \& A. Green, pers. comm. \\
\hline Polynesia & $\begin{array}{c}\text { American } \\
\text { Samoa }\end{array}$ & Rare & $\begin{array}{l}\text { Two individuals recorded out of a total of } 3115 \\
\text { individual parrotfishes. }\end{array}$ & Exploited & M. Page \& A. Green, pers. comm. \\
\hline Polynesia & Samoa & $\begin{array}{l}\text { Locally very } \\
\text { abundant }\end{array}$ & $\begin{array}{l}\text { At Nu'utele Island UVC abundance }=20 \mathrm{~g} \mathrm{~m}^{-2} \text {, } \\
\text { other parrotfish combined }=14 \mathrm{~g} \mathrm{~m}^{-2}\end{array}$ & Subsistence and artisanal & Samoilys \& Carlos, 1991 \\
\hline
\end{tabular}


Table 2. Contd.

\begin{tabular}{|c|c|c|c|c|c|}
\hline Region & Country & $\begin{array}{l}\text { Categorical } \\
\text { abundance }\end{array}$ & Abundance data & Exploitation patterns & Source \\
\hline Polynesia & Cook Is. & Absent & Not thought to have ever been present & Parrotfish are primary target of fishers & $\begin{array}{l}\text { Preston, Lewis \& Sims, 1995; } \\
\text { R. Walter, pers. comm. }\end{array}$ \\
\hline Polynesia & Hawaii (NW) & Absent & Not thought to have ever been present & & Randall et al., 1993 \\
\hline Polynesia & Niue & Present & & $\begin{array}{l}\text { Parrotfish targeted using fish } \\
\text { drives or spear guns }\end{array}$ & Dalzell, Lindsay \& Patiale, 1993 \\
\hline Polynesia & Tuvalu & Uncommon & Has been observed on outer reefs $(15-20 \mathrm{~m})$ & $\begin{array}{l}\text { Parrotfish captured in nets and } \\
\text { fish drives }\end{array}$ & S. Sauni \& N. Apinelu, pers. comm. \\
\hline Polynesia & Tonga & Rare & $\begin{array}{l}\text { None seen in } \sim 200 \mathrm{~h} \text { of UVC in western Ha'apai } \\
\text { group in } 2001 \text {. One } 23 \mathrm{~kg} \text { specimen reported } \\
\text { as being landed in } 1994 \text { inshore fisheries } \\
\text { statistics }\end{array}$ & & $\begin{array}{l}\text { Tulua, Kave \& Matoto, } 1995 \text {; } \\
\text { N.K.D., pers. obs. }\end{array}$ \\
\hline Polynesia & Wake Is., USA & Common & & $\begin{array}{l}\text { Unlikely that this species is exploited. } \\
\text { Until recently that was a US military } \\
\text { base without an indigenous population. } \\
\text { All food is imported }\end{array}$ & Myers, 1999 \\
\hline E. Pacific & Galapagos & Absent & At least four parrotfish species present & & $\begin{array}{l}\text { Jennings, Brierley \& Walker, } \\
1994\end{array}$ \\
\hline C. Indian Ocean & Indonesia & Rare & $\begin{array}{l}\text { Seen in Bali and Sulawesi. Low densities observed } \\
\text { in the Tongean islands, central Sulawesi }\end{array}$ & $\begin{array}{l}\text { Heavy artisanal and commercial } \\
\text { fishing. }\end{array}$ & $\begin{array}{l}\text { Tomascik et al., 1997; Bellwood et al., } \\
\text { 2003; T. R. McClanahan, pers. comm. }\end{array}$ \\
\hline E. Indian Ocean & Malaysia & $\begin{array}{l}\text { Locally } \\
\text { common }\end{array}$ & Locally common only at Sipidan & No fishing at Sipidan & D. Perrine, pers. comm. \\
\hline E. Indian Ocean & Philippines & Rare & Only found in south (Negros Is.), and in Sulu Sea & $\begin{array}{l}\text { Heavy exploitation of reef fishes, } \\
\text { including destructive fishing }\end{array}$ & $\begin{array}{l}\text { D. Watson, C. Kennaman \& } \\
\text { G. Broad, pers. comm. }\end{array}$ \\
\hline C. Indian Ocean & Maldives & Uncommon & $\begin{array}{l}\text { Juveniles and adults seen on fisheries surveys } \\
\text { and tourist dives }\end{array}$ & Little exploitation of reef fishes & M. Saleem \& R. Ekeheien, pers. comm. \\
\hline W. Indian Ocean & Kenya & V. rare & Absent in UVC surveys & & McClanahan, 1994 \\
\hline W. Indian Ocean & Madagascar & Present & Captured in artisanal catches & & D. K. A. Barnes, pers. comm. \\
\hline W. Indian Ocean & Mauritius & V. rare & Not seen in diving surveys & Heavy subsistence and artisanal fishing & R. Klaus, pers. comm. \\
\hline W. Indian Ocean & Mozambique & Present & Captured in artisanal catches & & D. K. A. Barnes, pers. comm. \\
\hline W. Indian Ocean & Seychelles & V. rare & Rarely seen outside marine reserves & & E. Grandcourt \& S. Jennings, pers. comm. \\
\hline W. Indian Ocean & Socotra Is., Yemen & Uncommon & Low abundance & Fisheries target pelagic species only & R. Klaus, pers. comm. \\
\hline W. Indian Ocean & Somalia & Present & Seen on diving surveys & & T. R. McClanahan, pers. comm. \\
\hline W. Indian Ocean & Tanzania & V. rare & $\begin{array}{l}\text { Not seen at Mafia Is. in } 5000+ \\
\text { dives, rare in S. Tanzania }\end{array}$ & & $\begin{array}{l}\text { The Society for Environmental } \\
\text { Exploration \& I. Horsfall, pers. comm. }\end{array}$ \\
\hline Red Sea & & $\begin{array}{l}\text { Locally } \\
\text { common }\end{array}$ & & & $\begin{array}{l}\text { T. R. McClanahan, R. Ormond \& } \\
\text { C. Roberts, pers. comm. }\end{array}$ \\
\hline
\end{tabular}

GBR, Great Barrier Reef; UVC, underwater visual census; PNG, Papua New Guinea.

Categorical abundance is ranked as $\mathrm{v}$. rare $<$ rare $<$ uncommon $<$ common $<$ abundant.

'Present' denotes insufficient data to categorise abundance, 'absent' denotes biogeographic locations where the parrotfish may never have been present. 
Table 3. Local densities, exploitation patterns, categorical fishing pressures, and census details of the giant humphead parrotfish at six Indo-Pacific locations

\begin{tabular}{|c|c|c|c|c|c|}
\hline Location & $\begin{array}{l}\text { Species } \\
\text { abundance } \\
\left(\text { no. } \mathrm{km}^{-2}\right)\end{array}$ & Exploitation levels & $\begin{array}{l}\text { Fishing pressure } \\
\text { category }\end{array}$ & $\begin{array}{l}\text { Details of census } \\
\text { replicates }\end{array}$ & Source \\
\hline Australia, GBR & 3.046 & No-take marine reserve & 0 & $\begin{array}{l}\text { Three UVC transects, each } \\
400 \times 20 \mathrm{~m}\end{array}$ & $\begin{array}{l}\text { J. H. Choat, pers. } \\
\text { comm. }\end{array}$ \\
\hline Solomon Is. & 1.399 & $\begin{array}{l}\text { Subsistence, mainly with } \\
\text { handlines. Reef fishes } \\
\text { are not an important } \\
\text { source of revenue. }\end{array}$ & 1 & $\begin{array}{l}12 \text { UVC 7-m radius point } \\
\text { counts }\end{array}$ & Samoilys et al., 1995 \\
\hline Fiji, Lau Is. & 0.008 & $\begin{array}{l}\text { Heavy subsistence, spear } \\
\text { and line fishing yielding } \\
3.4-10.2 \mathrm{t} / \mathrm{km}^{2} / \mathrm{yr} \text {. }\end{array}$ & 2 & $\begin{array}{l}\text { Six UVC 7-m radius point } \\
\text { counts and } 1 \text { UVC } \\
\text { transect, each } 15 \times 140 \mathrm{~m}\end{array}$ & $\begin{array}{l}\text { Jennings \& Polunin, } \\
\text { 1995, } 1996\end{array}$ \\
\hline Fiji, Mamanuca Is. & 0.029 & $\begin{array}{l}\text { Artisanal and possibly } \\
\text { commercial fisheries using } \\
\text { spear and line fishing. }\end{array}$ & 2 & $\begin{array}{l}12 \text { UVC 7-m radius point } \\
\text { counts }\end{array}$ & Rawlinson et al., 1994 \\
\hline Tanzania & 0.000 & $\begin{array}{l}\text { Heavy artisanal and } \\
\text { commercial exploitation } \\
\text { using nets, handlines, some } \\
\text { dynamite, and yielding } \\
7-14 \mathrm{t} / \mathrm{km}^{2} / \mathrm{yr} \text {. }\end{array}$ & 3 & $\begin{array}{l}\text { Two UVC transects, each } \\
5 \times 100 \mathrm{~m}\end{array}$ & $\begin{array}{l}\text { McClanahan et al., } \\
1999\end{array}$ \\
\hline $\begin{array}{l}\text { Philippines, NW } \\
\text { Luzon, Bolinao }\end{array}$ & 0.000 & $\begin{array}{l}\text { Very heavy artisanal and } \\
\text { commercial exploitation, } \\
\text { using nets, spears, lines, } \\
\text { explosives and poisons, } \\
\text { yielding } 3-10 \mathrm{t} / \mathrm{km}^{2} / \mathrm{yr} \text {. }\end{array}$ & 3 & $\begin{array}{l}\text { Two UVC transects, each } \\
10 \times 100 \mathrm{~m} \text {. }\end{array}$ & McManus et al., 1992 \\
\hline
\end{tabular}

UVC, underwater visual census.

and Indonesia. Overall we found a negative correlation between a categorical measure of fishing intensity and local density across the Indo-Pacific Ocean. Such a large scale approach assumes that census estimates from different geographical locations are comparable, but this assumption is challenged by the knowledge that abundance estimates may vary with time of observation, observer and geographical location in addition to fishing pressure (e.g. Thompson \& Mapstone, 1997; Samoilys \& Carlos, 2000). Despite these potential problems a similar approach has proven informative and was used to infer declining rates of parrotfish bioerosion on Indo-Pacific reefs (Bellwood et al., 2003).

There are several reasons why the giant humphead parrotfish might be vulnerable to exploitation. Larger bodied species of fish tend to be more vulnerable to exploitation due to correlated demography and lower maximum population growth rates (Jennings, Reynolds \& Mills, 1998; Jennings, Reynolds \& Polunin, 1999; Reynolds, Jennings \& Dulvy, 2001; Reynolds, 2003). This pattern holds both for temperate teleosts with relatively simple life histories and also for some reef fish with more complex life histories including parrotfishes (Jennings et al., 1999). Both the nocturnal aggregative behaviour in shallow lagoon water or in reef caves and the daytime foraging of shoals in depths accessible by breath-hold and SCUBA divers may render this species vulnerable to capture throughout much of its adult life. Historically this species may have found refuge in deeper water and distant uninhabited reefs, however the widespread availability of powered craft, spear guns and diving equipment may have increased the catchability of this species over the last 100 years (Johannes, 1981; Hamilton, 2003; Aswani \& Hamilton, 2004). This species is highly prized by subsistence and artisanal communities in Palau and the Solomon Islands (Johannes, 1981; Aswani \& Hamilton, 2004). In the Lau group, Fiji, the respondents noted that giant humphead parrotfish was often captured for ceremonial events suggesting this species has a high cultural significance. The combination of intrinsic vulnerability, relatively high catchability and high cultural (and/or monetary) value combined with evidence for decline and local extinction suggests that fishing may have resulted in global rarity of this functionally important fish species.

\section{Informal data sources and detecting declines}

We have inferred that the rarity of this parrotfish is due to exploitation. This inference was based on the informal questioning of groups of Fijian villagers and fishers followed by discussion with local scientists and government officials and a search of government statistics and other 'grey' literature. Here we used a relatively coarse questionnaire technique to access traditional ecological knowledge in Fiji, asking simple, unambiguous questions of groups of informants. This should not preclude the use of a more 'anthropological approach' such as the use of subtly designed questionnaires and application to 
individual informants to gain further detail (Aswani \& Hamilton, 2004).

We have attempted to evaluate this information as judiciously as possible (Sadovy \& Cheung, 2003). As scientists, we would prefer to assess human impacts on the basis of quantitative abundance estimates throughout the species' geographical range and information on factors that may influence abundance, such as fishing intensity and catches, habitat quality and availability, competitors, predators and recruitment processes to satisfy a rigorous test of causality. Unfortunately the quantitative data required may be largely unavailable for a relatively scarce species that is rarely encountered by scientists conducting small-scale underwater visual census (UVC) work on coral reefs (Johannes, 1998; Sadovy \& Cheung, 2003). This informal approach can be used to guide focused research and larger-scale UVC survey effort, which would be required to determine global estimates of abundance or at least an abundance index which would prove useful for guiding future conservation and management efforts.

There is an increasing awareness that the judicious use of informal data sources can provide a valuable additional perspective on the behaviour, ecology, abundance, exploitation and the current and historical status of a species (Johannes, 1981; Neis et al., 1999; Johannes et al., 2000; Sadovy \& Cheung, 2003). A survey of fishers' knowledge and informal information sources was used to infer the near extinction of a large fish species, the Chinese bahaba, throughout its entire range along the Chinese coastline (Sadovy \& Cheung, 2003). This species disappeared virtually unnoticed by both fishers and the scientific community. Similarly the induced rarity of B. muricatum, a large conspicuous reef fish, has also been overlooked. In data-poor situations retrospective searches may provide the only pragmatic method of inferring whether a species is naturally rare or has declined or disappeared as a result of human activity. Informal methods could aid efforts to provide a more accurate estimate of the contemporary marine extinction rate.

\section{Acknowledgements}

We thank the staff of the Marine Studies Programme at the University of the South Pacific for providing facilities and support; the late Benedito Tikomainiusiladi for conducting the questionnaire survey; the Tui Nayau, chiefs and turaganikoro of all the islands for granting permission for this study and K. Wynn, R. Mitchell, D. Watson, C. Glendinning, A. Haddock, C. Gough and B. Vasconcellos for logistical support and field assistance. This compilation would not have been possible without the generosity of N. Apinelu, S. Aswani, D. K. A. Barnes, D. Bellwood, G. Broad, M. Calamia, J. H. Choat, P. Dalzell, T. Donaldson, R. Ekeheien, M. Francis, P. Geraghty, E. Grandcourt, A. Green, R. Hamilton, I. M. Horsfall, S. Jennings, C. Kennaman, R. Klaus, M. Kulbicki, P. Labrosse, T. R. McClanahan, R. F. G. Ormond, M. Page, D. Perrine, C. M. Roberts, Y. Sadovy, M. Saleem, M. Samoilys, S. Sauni, O. Taylor, C. C. Wabnitz and R. Walter. We are particularly indebted to the late Robert
E. Johannes for providing his insights, and to Simon Jennings and two anonymous referees for their comments, which substantially improved this manuscript. The Natural Environment Research Council, UK, funded this study and Defra contract (MFD 0729) contributed to its completion.

\section{REFERENCES}

Anonymous. (1970). The fisheries development program at Kia Island and its effect on kalia (Bulbometopon muricatus). Suva, Fiji: Department of Agriculture.

Anonymous. (1990). Fiji Fisheries Division, Annual Report 1990. Suva, Fiji: Ministry of Agriculture, Fisheries and Forests.

Anonymous. (1994). Report of the senate select committee on the protection of Fijian fishing grounds. Suva, Fiji: Parliament of Fiji.

Anonymous. (1998). Palau Domestic Fishing Laws. Koror, Republic of Palau: Division of Marine Resources.

Aswani, S. \& Hamilton, R. (2004). Integrating indigenous ecological knowledge and customary sea tenure with marine and social science for conservation of bumphead parrotfish (Bolbometopon muricatum) in the Roviana Lagoon, Solomon Islands. Environ. Conserv. 31: $1-15$.

Bellwood, D. R., Hoey, A. S. \& Choat, J. H. (2003). Limited functional redundancy in high diversity systems: resilience and ecosystem function on coral reefs. Ecol. Letts. 6: 281-285.

Brander, K. (1981). Disappearance of Common skate Raia batis from Irish Sea. Nature 290: 48-49.

Carlton, J. T., Geller, J. B., Reaka-Kudla, M. L. \& Norse, E. A. (1999). Historical extinctions in the sea. Annu. Rev. Ecol. Syst. 30: 525-538.

Casey, J. \& Myers, R. A. (1998). Near extinction of a large, widely distributed fish. Science 281: 690-692.

Cohen, J. (1988). Statistical power analysis for the behavioural sciences. New York: Lawrence Erlbaum Associates.

Couture, E. \& Chauvet, C. (1994). Growth of the green humphead parrotfish (Bolbometopon muricatum) and its exploitation in New Caledonia. Noumea, New Caledonia: South Pacific Commission, Fisheries Information Paper No. 4.

Dalzell, P. \& Adams, T. J. H. (1997). Sustainability and management of reef fisheries in the Pacific Islands. Proc. 8th Int. Coral Reef Symp. 2: 2027-2039.

Dalzell, P., Adams, T. J. H. \& Polunin, N. V. C. (1996). Coastal fisheries in the Pacific islands. Oceangr. Mar. Biol. 34: 395-531.

Dalzell, P., Lindsay, S. R. \& Patiale, H. (1993). Fisheries resources of the island of Niue. Noumea, New Caledonia: South Pacific Commission.

Donaldson, T. J. \& Dulvy, N. K. (2004). Threatened fishes of the world: Bolbometopon muricatum (Valenciennes, 1840) (Scaridae). Env. Biol. Fishes 70: 373.

Dulvy, N. K., Freckleton, R. P. \& Polunin, N. V. C. (2004). Coral reef cascades and the indirect effects of predator removal by exploitation. Ecol. Letts. 7: 410-416.

Dulvy, N. K., Mitchell, R. E.,Watson, D., Sweeting, C. \& Polunin, N. V. C. (2002). Scale-dependant control of motile epifaunal community structure along a coral reef fishing gradient. J. Exp. Mar. Biol. Ecol. 278: 1-29.

Dulvy, N. K., Sadovy, Y. \& Reynolds, J. D. (2003). Extinction vulnerability in marine populations. Fish \& Fisheries 4: 25-64.

Francis, M. P. (1993). Checklist of the coastal fishes of Lord Howe, Norfolk, and Kermadec Islands, Southwest Pacific Ocean. Pac. Sci. 47: 136-170.

Galzin, R. (1987). Structure of fish communities of French Polynesian coral reefs. II. Temporal scales. Mar. Ecol. Prog. Ser. 41: 137-145.

Gust, N., Choat, J. H. \& McCormick, M. I. (2001). Spatial variability in reef fish distribution, abundance, size, and biomass: a multi-scale analysis. Mar. Ecol. Prog. Ser. 214: 237-251.

Hamilton, R. (2003). The role of indigenous knowledge in depleting a limited resource - a case study of the humphead parrotfish (Bolbometopon muricatum) artisanal fishery in Roviana Lagoon, 
western Province, Solomon Islands. In Putting Fishers' Knowledge to Work: 68-77. Haggan, N., Brignall, C. \& Wood, L. (Eds). British Columbia: University of British Columbia, Fisheries Centre Research Reports.

Hawkins, J. P. \& Roberts, C. M. (2004). Effects of artisanal fishing on Caribbean coral reefs. Conserv. Biol. 18: 215-226.

Hawkins, J. P., Roberts, C. M. \& Clark, V. (2000). The threatened status of restricted-range coral reef fish species. Anim. Conserv. 3: 81-88.

Hilton-Taylor, C. (2000). IUCN Red List of threatened species. Gland, Switzerland: International Union for the Conservation of Nature.

Hudson, E. \& Mace, G. (1996). Marine fish and the IUCN Red List of threatened fish species. London: Zoological Society of London.

Hughes, T. P., Baird, A. H., Bellwood, D. R., Card, M., Connolly, S. R., Folke, C., Grosberg, R., Hoegh-Guldberg, O., Jackson, J. B. C., Kleypas, J., Lough, J. M., Marshall, P., Nystrom, M., Palumbi, S. R., Pandolfi, J. M., Rosen, B. \& Roughgarden, J. (2003). Climate change, human impacts, and the resilience of coral reefs. Science 301: 929-933.

Hutchings, J. A. (1996). Spatial and temporal variation in the density of northern cod and a review of the hypotheses for the stock collapse. Can. J. Fish. Aquat. Sci. 53: 943-962.

Hutchings, J. A. (2000). Collapse and recovery of marine fishes. Nature 406: 882-885.

Hutchings, J. A. (2001a). Conservation biology of marine fishes: perceptions and caveats regarding assignment of extinction risk. Can. J. Fish. Aquat. Sci. 58: 108-121.

Hutchings, J. A. (2001b). Influence of population decline, fishing, and spawner variability on the recovery of marine fishes. J. Fish. Biol. 59A: 306-322.

Jackson, J. B. C., Kirby, M. X., Berger, W. H., Bjorndal, K. A., Botsford, L. W., Bourque, B. J., Bradbury, R. H., Cooke, R., Erlandson, J., Estes, J. A., Hughes, T. P., Kidwell, S., Lange, C. B., Lenihan, H. S., Pandolfi, J. M., Peterson, C. H., Steneck, R. S., Tegner, M. J. \& Warner, R. R. (2001). Historical overfishing and the recent collapse of coastal ecosystems. Science 293: 629-637.

Jennings, S., Brierley, A. S. \& Walker, J. W. (1994). The inshore fish assemblages of the Galapagos archipelago. Biol. Conserv. 70: 49-57.

Jennings, S. \& Polunin, N. V. C. (1995). Effects of fishing on the biomass and structure of target reef fish communities. J. Anim. Ecol. 33: 400412.

Jennings, S. \& Polunin, N. V. C. (1996). Effects of fishing effort and catch rate upon the structure and biomass of Fijian reef fish communities. J. Appl. Ecol. 33: 400-412.

Jennings, S. \& Polunin, N. V. C. (1997). Impacts of predator depletion by fishing on the biomass and diversity of non-target reef fish communities. Coral Reefs 16: 71-82.

Jennings, S., Reynolds, J. D. \& Mills, S. C. (1998). Life history correlates of responses to fisheries exploitation. Proc. R. Soc. Lond. Ser. B 265: 333-339.

Jennings, S., Reynolds, J. D. \& Polunin, N. V. C. (1999). Predicting the vulnerability of tropical reef fishes to exploitation using phylogenies and life histories. Conserv. Biol. 13: 1466-1475.

Johannes, R. E. (1981). Words of the Lagoon. Berkley, California: University of California.

Johannes, R. E. (1998). The case for data-less marine resource management: examples from tropical nearshore finfisheries. Trends Ecol. Evol. 13: 243-246.

Johannes, R. E., Freeman, M. M. R. \& Hamilton, R. J. (2000). Ignore fisher's knowledge and miss the boat. Fish \& Fisheries 1: 257 271.

Jonzén, N., Lundberg, P., Cardinale, M. \& Arrhenius, F. (2001). Variable fishing mortality and the possible commercial extinction of the eastern Baltic cod. Mar. Ecol. Prog. Ser. 210: 291-296.

Kitalong, A. \& Dalzell, P. (1994). A preliminary assessment of the status of inshore coral reef fish stocks in Palau. Inshore Fisheries Research Project Technical Document No. 6. Noumea, New Caledonia: South Pacific Commission.

Ledua, E. \& Vuki, V. (1998). The inshore fisheries resources of Fiji. In VIIIth Pacific Science Inter-Congress, Fisheries and Marine
Resources: 45-59. South, R., Seeto, J. \& Bulai, N. (Eds). University of the South Pacific: Marine Studies Technical Report No. 3/98.

Lieske, E. \& Myers, R. (1994). Coral reef fishes Indo-Pacific and Caribbean. London: HarperCollins Publishers.

Mace, G. M. \& Hudson, E. J. (1999). Attitudes towards sustainability and extinction. Conserv. Biol. 13: 242-246.

McClanahan, T. R. (1994). Kenyan coral reef lagoon fish - effects of fishing, substrate complexity, and sea-urchins. Coral Reefs 13: 231241.

McClanahan, T. R., Muthiga, N. A., Kamukuru, A. T., Machano, H. \& Kiambo, R. W. (1999). The effects of marine parks and fishing on coral reefs of northern Tanzania. Biol. Conserv. 89: 161-182.

McKinney, M. L. (1998). Is marine biodiversity at less risk? evidence and implications. Divers. Dist. 4: 3-8.

McManus, J. W., Nañola, C. L., Reyes, J. R. B. \& Kesner, K. N. (1992). Resource ecology of the Bolinao coral reef system. Manila, Philippines: ICLARM Stud. Rev. 22.

Mumby, P. J., Harbourne, A. R., Raines, P. S. \& Ridley, J. M. (1995). A critical assessment of data derived from Coral Cay Conservation volunteers. Bull. Mar. Sci. 56: 737-751.

Myers, R. A., Hutchings, J. A. \& Barrowman, N. J. (1997). Why do fish stocks collapse? The example of cod in Atlantic Canada. Ecol. Applic. 7: 91-106.

Myers, R. A. \& Worm, B. (2003). Rapid worldwide depletion of predatory fish communities. Nature 423: 280-283.

Myers, R. F. (1999). Micronesian reef fishes. Guam: Coral Graphics.

Neis, B., Schneider, D. C., Felt, L., Haedrich, R. L., Fischer, J. \& Hutchings, J. A. (1999). Fisheries assessment: what can be learned from interviewing resource users. Can. J. Fish. Aquat. Sci. 56: 19491963.

Nichols, P. V. (1991). Republic of Palau Marine Resources Profiles. Noumea, New Caledonia: Forum Fisheries Agency Report No.91/59.

Orcutt, A. M., Cordy, R., Rappa, P. J. \& Smith, B. D. (1989). Yap proper coastal resource inventory. Honolulu, Hawaii: University of Hawaii.

Powles, H., Bradford, M. J., Bradford, R. G., Doubleday, W. G., Innes, S. \& Levings, C. D. (2000). Assessing and protecting endangered marine species. ICES J. Mar. Sci. 57: 669-676.

Preston, G. L., Lewis, A. D. \& Sims, N. (1995). The marine resources of Palmerston Islands, Cook Islands. Noumea, New Caledonia: South Pacific Commission.

Randall, J. E. \& Bruce, R. W. (1983). The parrotfishes of the subfamily Scarinae of the western Indian Ocean with descriptions of three new species. Ichthyol. Bull. 47: 39.

Randall, J. E., Earle, J. C., Pyle, R. C., Parrish, J. D. \& Hayes, T. (1993). Annotated checklist of the fishes of Midway Atoll, Northwestern Hawaiian Islands. Pac. Sci. 47: 356-400,

Rawlinson, N. J. F., Milton, D. A., Blaber, S. J. M., Sesewa, A. \& Sharma, S. P. (1994). A survey of the subsistence and artisanal fisheries in rural areas of Viti Levu, Fiji. ACIAR Monogr. 35: 1-138.

Reynolds, J. D. (2003). Life histories and extinction risk. In Macroecology: 195-217. Gaston, K. J. \& Blackburn, T. J. (Eds). Oxford: Blackwell Publishing.

Reynolds, J. D., Dulvy, N. K. \& Roberts, C. M. (2002). Exploitation and other threats to fish conservation. In Fish and fisheries handbook: 319-341. Hart, P. J. B. \& Reynolds, J. D. (Eds). Oxford: Blackwell Science.

Reynolds, J. D., Jennings, S. \& Dulvy, N. K. (2001). Life histories of fishes and population responses to exploitation. In Conservation of exploited species: 147-168. Reynolds, J. D., Mace, G. M., Redford, K. H. \& Robinson, J. G. (Eds). Cambridge: Cambridge University Press.

Roberts, C. M. \& Hawkins, J. P. (1999). Extinction risk in the sea. Trends. Ecol. Evol. 14: 241-246.

Ruddle, K. (1996). Geography and human ecology of reef fisheries. In Reef fisheries: 137-160. Polunin, N. V. C. \& Roberts, C. M. (Eds). London: Chapman and Hall.

Sadovy, Y. (2001). The threat of fishing to highly fecund fishes. J. Fish. Biol. 59A: 90-108. 
Sadovy, Y. \& Cheung, W. L. (2003). Near extinction of a highly fecund fish: the one that nearly got away. Fish \& Fisheries 4: 86-99.

Samoilys, M. \& Carlos, G. (1991). A survey of reef fish stocks in Western Samoa: application of underwater visual census methods for fisheries personnel. Cairns, Australia: Department of Primary Industries, Queensland.

Samoilys, M. A. \& Carlos, G. (2000). Determining methods of underwater visual census for estimating the abundance of coral reef fishes. Environ. Biol. Fish. 57: 289-304.

Samoilys, M., Fuentes, H., Tuwai, I., Tikomainiusiladi, B., Leqata, J., Die, D., Wilson, M., Connell, S., Lincoln Smith, M. \& Watson, R. (1995). Application of underwater visual census to assessing coral reef fish stocks in the tropical Pacific. Cairns, Australia: Australian Centre for International Agricultural Research, Department for Primary Industries, Queensland.

Spalding, M. D., Ravilious, C. \& Green, E. P. (2001). World atlas of coral reefs. Berkeley: University of California Press.

St. John, J., Russ, G. R. \& Gladstone, W. (1990). Accuracy and bias of visual estimates of numbers, size structure and biomass of a coral reef fish. Mar. Ecol. Prog. Ser. 64: 253-262.
Thompson, A. A. \& Mapstone, B. D. (1997). Observer effects and training in underwater visual surveys of reef fishes. Mar. Ecol. Prog. Ser. 154: 53-63.

Thompson, A. A. \& Mapstone, B. D. (2002). Intra- versus inter-annual variation in counts of reef fishes and interpretations of long-term monitoring studies. Mar. Ecol. Prog. Ser. 232: 247-257.

Tomascik, T., Mah, A. J., Nontji, A. \& Moosa, M. K. (1997). The ecology of the Indonesian seas. Singapore: Periplus Editions.

Tulua, S., Kava, V. \& Matoto, S. V. (1995). Inshore fisheries statistics. Nuku'alofa: Ministry of Fisheries, Kingdom of Tonga/Japan International Cooperation Agency.

Williams, D. M. M. (1990). Shallow water reef fishes. In Vanuatu marine resources: report of a biological survey: 66-76. Done, T. J. \& Navin, K. F. (Eds). Townsville, Queensland: Australian Institute for Marine Science.

Wing, S. R. \& Wing, E. S. (2001). Prehistoric fisheries in the Caribbean. Coral Reefs 20: 1-8.

Wright, A. \& Richards, A. H. (1985). A multispecies fishery associated with coral reefs in the Tigak Islands, Papua New Guinea. Asian Mar. Biol. 2: 69-84 